\title{
THE ROLE OF HUMAN RIGHTS IN THE PROCESS OF CONSTITUTIONALIZATION OF INTERNATIONAL LAW
}

O PAPEL DOS DIREITOS HUMANOS NO PROCESSO DE CONSTITUCIONALIZAÇÃO DO DIREITO INTERNACIONAL

EL PAPEL DE LOS DERECHOS HUMANOS EN EL PROCESO DE CONSTITUCIONALIZACIÓN DEL DERECHO INTERNACIONAL

\section{Angela Jank Calixto ${ }^{1}$}

\section{Luciani Coimbra de Carvalho²}

Licença CC BY:

Artigo distribuído sob os termos Creative Commons, permite uso e distribuição irrestrita em qualquer meio desde que $o$ autor credite a fonte original.

\begin{abstract}
This paper aims to verify how the development of International Human Rights Law demonstrates the existence of a constitutional tendency in International Law. Adopting the deductive method, it analyzes the main doctrines that recognize the possibility of International Law assuming constitutional characteristics, the historical context that led to the emergence of these ideas, and the advances brought by the IHRL. It was verified that the development of the IHRL has consolidated means of affirming the existence of a process of constitutionalization, giving greater legitimacy and force to the international norms intended to protect individuals.
\end{abstract}

KEYWORDS: International Human Rights Law; Constitutionalization of International Law; Human Rights.

RESUMO: Este trabalho tem como objetivo verificar como o desenvolvimento do Direito Internacional dos Direitos Humanos (DIDH) demonstra a existência de uma tendência constitucional no Direito Internacional. Com a adoção do método dedutivo, foi realizada uma análise das principais doutrinas que reconhecem a possibilidade de o Direito Internacional assumir características constitucionais, do contexto histórico que permitiu o surgimento de tais ideias e dos avanços trazidos pelo DIDH. Verificou-se que o desenvolvimento do DIDH tem meios consolidados para afirmar a existência de um processo de constitucionalização, conferindo maior legitimidade e força às normas internacionais destinadas a proteger os indivíduos.

PALAVRAS-CHAVES: Direito Internacional dos Direitos Humanos; Constitucionalização do Direito Internacional; Direitos Humanos.

\footnotetext{
$1 \quad$ PhD student in Law at USP - Universidade de São Paulo - SP (Brazil). Master's Degree in Law from UFMS - Universidade Federal de Mato Grosso do Sul. Second Vice-Chair of the Federação Nacional dos Pós-graduandos em Direito [National Federation of PhD Students in Law]. Editorial assistant for Revista Direito UFMS. Legal Analyst of the TJMS. Email: angelajcalixto@gmail.com.

2 PhD and Master's Degree in State Law from Pontifícia Universidade Católica de São Paulo - PUCSP. Adjunct Professor on the Postgraduate and Master's Degree programs in Law at Universidade Federal de Mato Grosso do Sul - UFMS, Mato Grosso do Sul (Brazil). Linked to the UFMS - Mato Grosso do Sul (Brazil). Email: lucianicoimbra@hotmail.com.
} 
RESUMEN: Este trabajo tiene como objetivo verificar como el desarrollo del Derecho Internacional de los Derechos Humanos (DIDH) demuestra la existencia de una tendencia constitucional en el Derecho Internacional. Con la adopción del método deductivo, fue realizado un análisis de las principales doctrinas que reconocen la posibilidad del Derecho Internacional asumir características constitucionales, del contexto histórico que permitió el surgimiento de tales ideas y de los avances traídos por el DIDH. Se verificó que el desarrollo del DIDH tiene medios consolidados para afirmar la existencia de un proceso de constitucionalización, comprobando mayor legitimidad y fuerza a las normas internacionales destinadas a proteger los individuos.

PALABRAS CLAVE: Derecho Internacional de los Derechos Humanos; Constitucionalización del Derecho Internacional; Derechos Humanos.

\section{INTRODUCTION}

Since the second half of the 20th century, the need for concrete measures by the international community has increased, in order to strengthen the protection of Human Rights and prevent new atrocities, like those committed during World War II. Due to this need to protect human rights at an international level, to avoid new abuses by States against individuals, the global legal landscape has undergone a permanent and accelerated process of change. In this scenario, a new specialized branch of International Law has emerged: International Human Rights Law (IHRL), aimed precisely at ensuring the protection of the individual.

The development of this specialized branch of International Law has led to the idea that a process of constitutionalization of International Law is in progress, based on the understanding that the publication of norms with constitutional content at international level, and the creation of international bodies to hold States accountable for their actions and omissions, leads to a process in which International Law assumes constitutional characteristics. The direct consequence of this understanding is the formation of the idea that because of this process, International Law can be conceived as a legal system that is binding on all States, precisely because it is seen as an autonomous constitutional system.

Despite the controversies surrounding the above affirmation, i.e., that the IHRL is an autonomous constitutional and totally binding system, it is important to note that the development of the IHRL in the global scenario has, in fact, consolidated means of asserting the existence of a process of constitutionalization of International Law, contributing to the direct tutelage of Human Rights around the globe. In order to demonstrate this process and the benefits of the assumption of constitutional characteristics by the international order, it is necessary to understand the basis for the affirmation that IHRL constitutionalized the international order, and to highlight the contributions promoted by this specialized branch for the protection of Human Rights. 
This paper analyzes the main theories that recognize the possibility of International Law assuming constitutional characteristics, the historical context that allowed the emergence of the idea that International Law constitutionalized itself, and the advances made by IHRL for the process of constitutionalization, conferring greater legitimacy and legal force to external norms. This paper uses exploratory, descriptive and bibliographical research, and adopts deductive and historical methods.

\section{THEORETICAL ASSUMPTIONS FOR THE PROCESS OF CONSTITUTIONALIZATION OF INTERNATIONAL LAW}

In order to properly evidence the assumption by International Law of aspects of Constitutional Law and, thus, understand the idea that international norms (concerning IHRL) have constitutional value and must be observed by all States, it is first necessary to discuss the development, among the leading theorists, of the meaning of constitutionalization of International Law. The concept of Constitution has long been discussed; it has been treated in different ways by important classical theorists, such as Hans Kelsen ${ }^{3}$, Rudolf Smend ${ }^{4}$, Konrad Hesse ${ }^{5}$ and Carl Schmitt ${ }^{6}$, among others. However, such discussions tended to focus only on the concept of the Constitution as essentially linked to the State (the modern concept of Constitution), rejecting the possibility of the concept being used in an international context.

Bardo Fassbender emphasizes that the evolution of the study of the constitutional discourse in International Law can only be evidenced after the development of three main schools: the Vienna School, the New Haven School and the Doctrine of the International Community School, each of which presents a constitutional speech from a differentiated perspective, all with the intention, however, of demonstrating the possibility of recognition of constitutional norms in the international order ${ }^{7}$.

The importance of such schools is that, from the theories they put forth, the possibility of using the concept of Constitution and constitutionalism in other orders, not strictly linked to the figure of the State, was developed, thus allowing the development of the idea of a process of constitutionalization

3 For Kelsen, in his positive pure theory of Law, the Constitution is conceived as the highest hierarchical norm within national law, to which all others must conform to be considered valid. In: KELSEN, Hans. Teoria Geral do Direito e do Estado. Translation of Luis Carlos Borges. São Paulo: Martins Fontes, 2000.

4 For the author, whose theory is called "Theory of Integration" the Constitution, as a positive legal order of a State, has an eminently integrative and conciliatory function, that is, it is destined mainly to promote the integration of society within a given State. In: SMEND, Rudolf. Constitución y Derecho Constitucional. Madrid: Centro de Estudios Constitucionales, 1985.

5 Konrad Hesse describes the Constitution as a fundamental legal order of the public community, establishing a guideline of principles on which the political unit should be based and the activities that must be carried out. The Constitution thus establishes the legal basis by which the community of a State is governed, establishing essential aspects of the legal system as a whole. In: HESSE, Konrad. Elementos de Direito Constitucional da República Federal da Alemanha. Translation of Luís Afonso Heck. Porto Alegre: Editora Safe, 1998.

6 Carl Schmitt, despite identifying the Constitution as a concept related to the notion of State, presents it under a very different approach from the other authors, view it not as a norm, but as a fundamental political decision of the entity in charge of the function of establishing it. The author develops, therefore, a concept of constitution not linked to its formal aspects. In: SCHMITT, Carl. Teoria de la Constitución. Madrid: Alianza editorial, 1982.

7 FASSBENDER, Bardo. The United Nations Charter as Constitution of the International Community. Columbia Journal of Transnational Law, v. 36, n. 3, p. 529-619, 1998. 
of the international order. Since then, the notion of the use of such terms exclusively in its relation with the figure of the State is surpassed, making it possible to recognize a constitutional process beyond the nation or territory. ${ }^{8}$ Fassbender points out that only the authors of the above-mentioned law schools were able to explain the reasons and consequences of the use of such terms when speaking of International Law. ${ }^{9}$

With regard to the Vienna School, the ideas of Alfred Verdross, student of Hans Kelsen, stand out, the author having tried since 1926 to use the term Constitution when referring to international standards. Although the theorist at first understood that the Constitution in International Law, in the broad sense, referred to the most important rules of International Law ${ }^{10}$, a definition that limited its coverage, afterword he changed his understanding, to the recognize the Charter of the United Nations as the general text of International Law, due to the fact that currently almost all States accept it as binding, in a way that such instrument, in the authors perspective, could be conceived as the international Constitution. ${ }^{11}$

In this School, a normative analysis of the constitutional discourse was developed, the Constitution being conceived as a set of rules whose existence is a precondition for the validity of other norms and as derived from an agreement between States in a given period of history. ${ }^{12}$ The international Constitution, as referred by Verdross, would therefore be conformed by the principles of International Law in charge of determining their sources, their subjects, the paths for its application and the powers of the States, ${ }^{13}$ its recognition in the international sphere being an essential aspect for the recognition of the legitimacy and validity of international standards.

Likewise, The New Haven School also contributed significantly to development of the notion of constitutionalization of International Law, even though it presented a diametrically opposed view to the above. That's because such school parted from a realistic position, criticizing the positivist conception of the international order.

Starting from a concern with the description and the evaluation of the whole constitutional process and not merely with the description of the formal structures of government (as in the Vienna School), the New Haven School was able to demonstrate the interdependence between law and policy, stressing that the international Constitution must be perceived in the interrelation between law

$8 \quad$ PETERS, Anne. Compensatory Constitutionalism: the function and potential of fundamental international norms and structures. Leiden Journal of International Law, Leiden, v. 19, n. 3, p. 579-610, 2006.

9 FASSBENDER, Bardo. The United Nations Charter as Constitution of the International Community, p. 538.

10 VERDROSS, Alfred. Die Verfassung der Völkerrechtsgemeinschaft. Vienna: J. Springer, 1926.

11 VERDROSS, Alfred; SIMMA, Bruno. Universelles Völkerrecht: Theorie und Praxis. 3. ed. Berlin: Duncker \& Humboldt, 1984.

12 FASSBENDER, Bardo. The United Nations Charter as Constitution of the International Community, p. 541-544.

13 ACOSTA ALVARADO, Paola Andrea. Del diálogo interjudicial a la constitucionalización del derecho internacional: la red judicial latinoamericana como prueba y motor del constitucionalismo multinivel. 2013. Thesis (PhD in International Law and International Relations) - Complutense University of Madrid, Ortega e Gasset University Research Institute, Madrid, 2013, p. 171. 
and the entire social process of the international community. ${ }^{14}$ Such school allowed an approximation between law and society, pushing the study of law away from the mere analysis of the structures of the system and allowing the understanding that a valid Constitution is the document that regulates, in an effective way, the social process.

Finally, Fassbender emphasizes the importance of the Doctrine of the International Community School, which presents a more extensive and progressive view of the constitutional discourse, based on the ideas of Hermann Mosler and Tomuschat, for whom the international community is a legal community, that is, is governed by law, there being an interdependence between the international Constitution and the international community. ${ }^{15}$

In the same way as the Vienna School, this school defends the existence of basic norms that condition the existence and validity of the law. There are differences between the ideas developed, however, which lie in the fact that the Vienna School ideas are based on a voluntary aspect, requiring State consensus for the recognition of the existence of an international Constitution, in addition to stressing that the existence of such Constitution is due to the need to provide a coherent structure to the international legal system in order to convey legitimacy and validity to the standards of such systems, while the Doctrine of the International Community School rejects the need of a voluntary adherence and defends that the existence of an international Constitution is conditioned only to the existence of common values at the global level, which require enhanced protection and, therefore, justify the presence of constitutional norms. ${ }^{16}$

In any case, regardless of the perspective adopted, it is important to understand that all schools show the possibility of using the term "Constitution" while referring to some international standards, especially when parting from the idea of the existence of basic rules in International Law to which the international community must observe. Such perspective contributes to the analysis of the process of constitutionalization of the law, the above mentioned schools establishing the presuppositions for the recognition of constitutional character of international standards.

In fact, after the development of the above-mentioned doctrines, there was a significant increase in the study of the theme, with the emergence of numerous other theories aimed at demonstrating the correlation between Constitutional and International Law. Because the constitutional discourse is seen today as a response to the complexity of International Law, a number of ideas by different theorists seeking to demonstrate in what sense it is possible to affirm the existence of a process of constitutionalization of International Law were developed, in order to face the most varied

FASSBENDER, Bardo. The United Nations Charter as Constitution of the International Community, p. 545.

FASSBENDER, Bardo. The United Nations Charter as Constitution of the International Community, p. 546-547.

ACOSTAALVARADO, Paola Andrea. Del diálogo interjudicial a la constitucionalización del derecho internacional: la red judicial latinoamericana como prueba y motor del constitucionalismo multinivel, p. 173. 
global challenges. Among the main theories that emerged, Acosta Alvarado points out that these can be grouped in a variety of ways, depending on the perspective adopted to characterize the constitutionalization process. As the author emphasizes:

[...] one could think of a classification in terms of its extension, i.e., as a global constitutionalism, in a functional, a regional, a multilevel constitutionalism that is structured around one or more of these nuances. One could also group constitutional ideas according to their scope in normative terms, i.e., according to whether the intention is to form a single constitutional text, or to recognize the constitutional nature of various dispersed norms, or to assume a plurality of constitutional systems. Similarly, one could speak of an organic constitutionalism, a procedural, or a foundational constitutionalism, depending on whether the goal is to form a constitutional structure, or to constitutionalize certain procedures, or whether the constitutionalism is intended to function as a legitimate source of international law (our translation). ${ }^{17}$

There is no unanimity or complete consistency in the use of the terms "constitution" or "constitutionalism" by the different theorists. Therefore, for the purpose of this paper, the definition presented by Paola Acosta Alvarado on the process of constitutionalization of International Law will be used, since it parts both from a formal and from a substantial position of this process, demonstrating which of the instruments and values that have been developed in International Law serve as evidence of the formation of an International Constitutional Law.

From this perspective, constitutionalization can be evidenced by the mere emergence of instruments and structures of a constitutional nature in the international order and the consecration of values and constitutional principles in the international legal scenario, ${ }^{18}$ recognizing, based on the ideas of Anne Peters ${ }^{19}$, that the process of constitutionalization of International Law is, therefore, the political and intellectual movement that intends to "endow international law with constitutional characteristics, that is, to seek to make International Law a system that justifies, organizes and limits the exercise of power and that, therefore, respects the principles of legality, separation of powers, democratic rule of law and human rights"20.

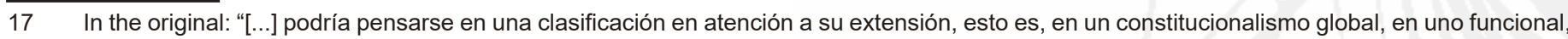
en uno regional, en uno multinivel que se estructure atendiendo a uno o a varios de estos matices. También podrían agruparse las ideas constitucionales atendiendo a su alcance en términos normativos, es decir, según si lo que se pretende es la conformación de un solo texto constitucional, el reconocimiento de la naturaliza constitucional de varias normas dispersas o la asunción de una pluralidad de regímenes constitucionales. Igualmente, podría hablarse de un constitucionalismo orgánico, de uno procedimental o de un constitucionalismo fundacional dependiendo de si lo que se persigue es la conformación de una estructura constitucional, de la constitucionalización de ciertos procedimientos o si lo que se pretende es que el constitucionalismo funja como fuente legitimadora del derecho internacional". In: ACOSTAALVARADO, Paola Andrea. Del diálogo interjudicial a la constitucionalización del derecho internacional: la red judicial latinoamericana como prueba y motor del constitucionalismo multinivel, p. 189.

18 ACOSTA ALVARADO, Paola Andrea. Del diálogo interjudicial a la constitucionalización del derecho internacional: la red judicial latinoamericana como prueba y motor del constitucionalismo multinivel, p. 177-178.

19 PETERS, Anne. Compensatory Constitutionalism: the function and potential of fundamental international norms and structures, p. 579-610.

20 In the original: "[...] dotar al derecho internacional de rasgos constitucionales, esto es, pretende que este derecho sea un ordenamiento que fundamente, organice y limite el ejercicio del poder y que, por lo tanto, sea respetuoso del principio de legalidad, la separación de poderes, el régimen democrático y los derechos humanos". 
In otherwords, it is the process in which International Law assumes characteristics of Constitutional Law, establishes limits to the unrestricted power of the State, establishes minimum parameters of coherence and international protection, and takes care of the interests of the international community.

Thus, the phenomenon of constitutionalization of International Law involves the application of constitutional principles to International Law, such as the rule of law, checks and balances, protection of Human Rights and Democracy, as a way of promoting the efficiency of the international order. ${ }^{21}$ From this perspective - which, in the view of Perenice ${ }^{22}$ is a post-national one - a Constitution can be any normative instrument, national or supranational aimed at the establishment, organization and limitation of the public authority and the power of the Executive, Legislative and Judicial Powers by the people.

After delimiting the theoretical framework of the constitutionalization process, and establishing what can be considered a Constitution and what can be characterized as a process of constitutionalization, the factors that led to the emergence of the IHRL will be discussed, seeking to show how it has contributed to the process of constitutionalization of the international order.

\section{ASSUMPTIONS FOR THE PROCESS OF CONSTITUTIONALIZATION OF INTERNATIONAL LAW: THE HISTORICAL EVOLUTION OF IHRL AND THE JURIDIFICATION OF INTERNATIONAL RELATIONS}

Constitutionalization of International Law, as indicated at the beginning of this article, is seen as a phenomenon by which International Law "mimics institutes once reserved for Constitutional Law, e.g., the creation of tribunals, protection of fundamental rights, rule of law, direct access of individuals, trial of individuals in the criminal field (even with perpetual punishment), among others" ${ }^{23}$

$21 \quad$ PETERS, Anne. Compensatory Constitutionalism: the function and potential of fundamental international norms and structures, p. 583

22 PERENICE, Ingolf. The Treaty of Lisbon: Multilevel Constitutionalism in action. Columbia Journal of European Law, Columbia, n. 15, p. 16-17, 2009.

23 In the original: "mimetiza institutos outrora reservados ao Direito Constitucional, como, v.g. criação de tribunais, proteção de direitos fundamentais, rule of law, acesso direto de indivíduos, julgamento de indivíduos no campo penal (até com pena de caráter perpétuo), entre outros". In: RAMOS, André de Carvalho. A relação entre o Direito Internacional e o Direito interno no contexto da pluralidade de ordens jurídicas. In: BRANDT, Leonardo Nemer Caldeira (Org.). Brazilian Yearbook of International Law. Belo Horizonte: CEDIN, 2012, v. 1, n. 12, p. 105. 


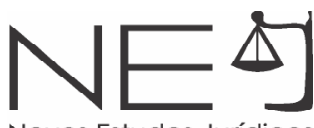

The initial development of the constitutionalization of International Law occurred with the emergence of Humanitarian Law, the League of Nations and the International Labor Organization, considered the historical precedents of the current protection of Human Rights. These three systems, effectively, refined the status of the individual on the international scene, placing the individual as the true subject (and not only the object) of International Law. ${ }^{24}$

These institutes contributed to the process of constitutionalization by ensuring minimum standards for working conditions, by establishing the maintenance of peace and international security as international goals, and by protecting fundamental rights in situations of armed conflict, all of which projected the issue of Human Rights at international level. ${ }^{25}$

However, it was only after World War II that IHRL and consequently, the process of constitutionalization were consolidated, as a response to the atrocities committed in that period and the emerging belief that new atrocities could be prevented by having an effective international systematic to protect Human Rights.

As Pedro Luño ${ }^{26}$, cited by Carvalho ${ }^{27}$, emphasizes, this process of constitutionalization of International Law is due, in essence, to a series of events that were harmful to the freedom of men, as these events led to the struggle to ensure rights for all, to be protected at the international level. Similarly, in the view of Richard Pierre Claude and Burns H. Weston ${ }^{28}$, international constitutionalization and the consequent use of the term "International Human Rights" essentially derives from a multidimensional program of legal and political struggles for the proper observance of fundamental rights.

It was in this scenario, with the pressing need to protect to Human Rights, that International Human Rights Law (IHRL) was consolidated, with the primary purpose of conferring plain effectiveness to Human Rights through the establishment of international norms that protect human dignity, freedom and equality, as well as through the provision of legal and political instruments for the implementation of such rights. ${ }^{29}$ Only then does the protection of these rights become a matter of legitimate interest and international concern. But a State does not, by itself, have the conditions to

24 Until the transformation of International Law after World War II, the understanding that this branch of law was destined only to regulate relations between States, only these being conceived as subjects of International Law, prevailed in the traditional doctrine. In this sense Thomas Buergenthal, cited by Piovesan, emphasizes that "traditional International Law is defined as the Law that regulates relations exclusively between State. Thus, under this approach, only States were subjects of International Law and only States could have rights under this Law. It was inconceivable that individuals had international rights. They were seen as objects, not as subjects of International Law. Consequently, human rights were conceived as matters concerning only the domestic jurisdiction of each State. This principle denied other States the right to intercede or intervene in cases where nationals of a State have their rights violated by him" (our translation). In: PIOVESAN, Flávia. Direitos Humanos e o Direito Constitucional Internacional. 14. ed. São Paulo: Saraiva, 2013, p. 219.

25 PIOVESAN, Flávia. Direitos Humanos e o Direito Constitucional Internacional, p. 190.

26 LUÑO, Pedro. Los derechos fundamentales. 8. ed. Madrid: Editorial Tecnos, 2004, p. 34.

27 CARVALHO, Oswaldo Ferreira de. A constitucionalização e a internacionalização dos direitos fundamentais. Public Law Review, v. 8, n. 43, p. 46-64, 2011.

28 CLAUDE, Richard Pierre; WESTON, Burns H. (Ed.). Human rights in the world community: issues and action. Philadelphia: University of Pennsylvania Press, 1989, p. 04.

29 TAIAR, Rogério. Direito Internacional dos Direitos Humanos: uma discussão acerca da relativização da soberania face à efetivação da proteção internacional dos Direitos Humanos. 2009. Thesis (PhD in Human Rights) - University of São Paulo, São Paulo, 2009, p. 232. 
face all the challenges presented, therefore Human Rights must transcend exclusive State competence to include shared international and local action. ${ }^{30}$ Based on the above, we affirm that the process of constitutionalization was closely linked to the emergence and expansion of IHRL, consequently adopting the nomenclature conferred by Ramos ${ }^{31}$, with the "juridification of international relations" that resulted from it, given that this process involves a tutelage, by the external order, of matters that were previously the exclusive domain of domestic jurisdictions, and a proliferation of international legal norms aimed at regulating post-war tensions.

The juridification of international relations led to quantitative and qualitative expansion of International Law: the quantitative expansion was the result of the intensive production of international standards in the most diverse fields of social conduct, while the qualitative expansion was the result of the strengthening of international procedures for interpreting and enforcing International Law ${ }^{32}$ (with the creation of international organizations ${ }^{33}$ and quasi-judicial bodies), thus overcoming decentralization and fragility in the implementation of international standards. ${ }^{34}$

With this expansion, an international system of protection of Human Rights was created, through the establishment of a system in which the international community could monitor and enforce the observance of those rights by all States. In this respect, it is clear that it is precisely due to the proliferation of international norms related to the protection of Human Rights, and the establishment of a system of monitoring and surveillance in the international context to ensure protection of the individual, that it can be said that International Law became constitutionalized during the last century.

This process originated with the creation of the United Nations and its main organs, namely, the General Assembly, the Security Council, the International Court of Justice, the Economic and Social Council, the Trusteeship Council, the Secretariat, and the UN Commission on Human Rights, as well as with the promulgation of the Charter of the United Nations, through which the constitutionalization movement was consolidated. The promulgation of the Charter of the United Nations, in 1945, can

30 PIOVESAN, Flávia. Direitos Humanos e o Direito Constitucional Internacional, p. 123.

31 RAMOS, André de Carvalho. A relação entre o Direito Internacional e o Direito interno no contexto da pluralidade de ordens jurídicas, p. 103.

32 RAMOS, André de Carvalho. A relação entre o Direito Internacional e o Direito interno no contexto da pluralidade de ordens jurídicas, p. 103104.

33 Over the last thirty years, we have seen the creation of several courts: the Court of the Sea, the Court of Economic Commission, the Central American Court of Justice, the Court of the Commonwealth of Independent States, the Court of Justice of the Common Market in South East and East Africa, the International Criminal Court, the Justice of the West African Economic Community, the Court of the Common Market of the Caribbean and the African Court on Human and Peoples' Rights, whereas prior to 1990 there were only six courts, the International Court of Justice, the Court of Justice of the European Communities, the Andino Pact, the Benelux Court of Justice, the European Court of Human Rights and the Court American Convention on Human Rights.

34 This decentralization and fragility stemmed, in particular, from the fact that there was an understanding that the State was the producer, recipient and primary interpreter of international standards. As a result, there was an understanding that States could bind themselves to International Law and at the same time, repeatedly violate international norms, using as a defense the claim that it was complying with the standards according to its interpretation of the treaty. On the other hand, with the normative extension of International Law, there was an emergence of increasingly invasive and regulatory obligations of the most varied facets of social life, as well as the establishment of international procedures aimed at ensuring the interpretation and implementation of international norms. In this way, an internationalist interpretation of the norms is obtained as a mechanism destined to ensure that States, in adhering to international treaties, do not fail to comply with its provisions under the pretext of holding a peculiar view on the subject. In: RAMOS, André de Carvalho. A relação entre o Direito Internacional e o Direito interno no contexto da pluralidade de ordens jurídicas, p. 103-104. 
therefore be established as the initial framework of the process of constitutionalization of International Law, and it is considered, by Sloboda and Tavares as the material constitution of the international society, as it "generates rights and obligations for third States, having established a normative hierarchy in International Law and, through secondary norms of recognition, trial and amendment, gives its bodies legislative and judicial powers"35.

Thus, the Charter of the United Nations led to a redefining of the fundamental values of the international community, and legal and institutional frameworks were established to limit State power. This process marked the beginning a new international order, characterized by the systemic integration of International Law with domestic law. ${ }^{36}$ The fundamental consequence of the UN Charter was to promote the internationalization of Human Rights, which have since ceased to be a matter of exclusive jurisdiction of the internal State jurisdiction. ${ }^{37}$

Later, in 1948, the Universal Declaration of Human Rights (UDHR) was promulgated. Developed with the aim of defining the list of Human Rights in the Charter of the United Nations, the UDHR became a code and common platform for action by the States. It introduced the contemporary concept of Human Rights in the international order, such rights being perceived as an interdependent and indivisible unity. ${ }^{38}$

Since then, with the growing international appreciation of Human Rights, there has been a proliferation of international treaties and bodies to ensure the implementation of the rights recognized in the UDHR which, although it constitutes a common code of conduct for the States, has no binding and binding legal force by itself. Therefore, an international systematic of monitoring and control (international accountability) ${ }^{39}$ was established, to enforce respect for Human Rights in all States. This, as highlighted, reveals the qualitative nature of International Law.

This process was initiated through the juridicization of the Declaration, which culminated in the drafting of two separate international treaties: the International Covenant on Civil and Political Rights and the International Covenant on Economic, Social and Cultural Rights. These two treaties, together with the UDHR, form the International Bill of Rights, inaugurating the global system of protection of Human Rights, which was subsequently expanded through several multilateral treaties on specific themes.

35 In the original: "gera direitos e obrigações para terceiros Estados, instituiu hierarquia normativa em direito internacional e, por meio de normas secundárias de reconhecimento, de julgamento e de alteração, confere a seus órgãos poderes legislativos e jurisdicionais". In: SLOBODA, Pedro Muniz Pinto; TAVARES, Sérgio Maia. Direito Interno e Direito Internacional: integração sistêmica. In: MENEZES, Wagner; ANUNCIAÇÃO, Clodoaldo Silva da; VIEIRA, Gustavo Menezes (Org.). Direito Internacional em expansão. Belo Horizonte: Arraes Editores, 2014 , p. 504. PIOVESAN, Flávia. Direitos Humanos e o Direito Constitucional Internacional, p. 196.

CASTILLO DAUDÍ, Mireya. Derecho internacional de los derechos humanos. 2. ed. Valencia: Tirant Lo Blanch, 2006.

PIOVESAN, Flávia. Direitos Humanos e o Direito Constitucional Internacional, p. 207.

PIOVESAN, Flávia. Direitos Humanos e o Direito Constitucional Internacional, p. 239. 
Over the years, new instruments have been adopted in the international scenario, all aimed at ensuring the international protection of Human Rights and reaffirming the primary need of the States to ensure this protection. These instruments include: the Convention on the Prevention and Punishment of the Crime of Genocide (1948), the Convention against Torture and Other Cruel, Inhuman or Degrading Treatment or Punishment (1984), the International Convention on the Elimination of all forms of Racial Discrimination (1965), the Convention on the Elimination of all forms of Discrimination against Women (1979), the Convention on the Rights of the Child (1989), the International Convention on the Protection of the Rights of all Migrant Workers and Members of their Families (1990), the Convention on the Rights of Persons with Disabilities (2006), all instituted with the purpose of guaranteeing, for all individuals, the exercise of their fundamental rights and freedoms.

These treaties, together with their Optional Protocols, add an important system of procedures to international accountability, with the institution of reporting and communication procedures, and in some cases, procedures for individual petitions to denounce violations of the rights protected by those treaties. ${ }^{40}$

Also, with the aim of ensuring greater international protection of Human Rights, international bodies have created to ensure accountability of States that violate Human Rights in their territories. For example, the International Criminal Court (1998) was set up to prosecute crimes against humanity, war crimes, crimes of genocide and crimes of aggression, acting as a complementary jurisdiction to the national courts. And in 2006, the International Human Rights Council was set up, replacing the former UN Human Rights Comission ${ }^{41}$, the main international body responsible for combating Human Rights violations.

International procedures (aligned with regional Human Rights procedures) were also developed during the same period), and contributed immensely to the protection of Human Rights. As pointed out by Acosta Alvarado, the proliferation of norms and international and regional instruments has brought numerous benefits to the development of Human Rights, because:

[...] they fill the gaps left by constitutional law and, thanks to them, it is possible to achieve the extraterritorial protection of individuals and the protection of non-citizens. In the same way, international standards of human rights attach a new layer of limits to the power of the State, the execution of which is not only the responsibility of national law, as has traditionally been the case, but also of other international actors. In general, the norms of international human rights law help to establish minimum standards of protection and raise the safeguard parameters; they facilitate communication between the different protection

40 PIOVESAN, Flávia. Direitos Humanos e o Direito Constitucional Internacional, p. 239.

41 The Human Rights Commission was transformed in 2006 into the UN Human Rights Council, with the aim of giving priority to the protection of the human person, emphasizing the view that peace, security and Human Rights are the three pillars of the UN system. The creation of the Human Rights stands out as another process stemming from the importance attached to protection human rights, and the council is responsible, inter alia, for UN Human Rights activities, to respond to violations of these rights and to seek establish a constructive dialogue with other bodies and organizations for the promotion and protection of human. In: PIOVESAN, Flávia. Direitos Humanos e o Direito Constitucional Internacional, p. 202. 
scenarios; they allow a degree of coherence to be achieved within the various components of international law and between the latter and the national legal systems, and finally; they serve as a parameter of the validity of constitutional and international norms and, in this sense, act as a guide for the legislator and, in general, as a parameter of conduct for the exercise of power. ${ }^{42}$

The proliferation of international and regional documents has therefore contributed to the development of the idea that the protection of Human Rights must go beyond borders, limiting the absolute sovereignty of States. Individuals are now seen as subjects of International Law, and they are provided with effective mechanisms to safeguard the rights protected by the international system.

The promulgation of international norms for the protection of Human Rights, and the creation of international bodies to ensure accountability, have enabled the protection of Human Rights in all parts of the globe to be supervised and monitored, cumulating in the recognition of the individual as an object of primordial importance. These processes were consolidated with the emergence and expansion of IHRL, and it is clear that International Law assumed many of the institutes previously reserved only to Constitutional Law.

There is a mimicry of institutes of Constitutional Law in the international sphere, which demonstrates, in essence, the existence of a process of constitutionalization of International Law.

\section{IMPORTANCE OF THE CONSOLIDATION OF THE CONSTITUTIONALIZATION PROCESS FOR THE PROTECTION OF HUMAN RIGHTS}

The recognition of the emergence and the existence of a common interest of the global community in protecting Human Rights, be they individual, civil, political, social, economic or cultural, was the key factor in the process of constitutionalization of International Law, as it was through this recognition that the international community began to develop norms and introduce mechanisms to ensure the implementation of these values and fundamental rights.

Peters emphasizes that "constitutionalization of public International Law means recognition of

42 In the original: "[...] ellas llenan los vacíos que dejan las cartas de derechos a nivel constitucional nacional, así mismo gracias a ellas se puede lograr la protección extraterritorial de los individuos y la protección de los no ciudadanos. De igual forma, las normas internacionales de derechos humanos adhieren una nueva capa de límites al poder del Estado cuya ejecución no compete, como tradicionalmente, sólo al derecho nacional, sino que ahora también le incumbe a otros actores internacionales. En general las normas del derecho internacional de los derechos humanos ayudan a establecer los estándares mínimos de protección y elevar los parámetros de salvaguarda, facilitan la comunicación entre los diversos escenarios de tutela, permiten alcanzar cierto grado de coherencia entre los diversos componentes del derecho internacional y entre este y los ordenamientos nacionales, finalmente, sirven como parámetro de validez de las normas, tanto constitucionales, como internacionales y en ese sentido se erigen como un derrotero para el legislador y, en general, como parámetro de conducta para el ejercicio del poder". In: ACOSTA ALVARADO, Paola Andrea. Del diálogo interjudicial a la constitucionalización del derecho internacional: la red judicial latinoamericana como prueba y motor del constitucionalismo multinivel, p. 204. 
interests of the community of states and the introduction of mechanisms for their implementation"43 and Acosta Alvarado clarifies that the main objectives of the process of constitutionalization of International Law were to recognize fundamental values that could serve as basis for International Law, such as democracy, peace, human dignity, among others, and to construct a normative framework to limit power and protect those values. ${ }^{44}$

The perception of the indispensability protecting and ensuring Human Rights leads, as has already been demonstrated, led to the consolidation of so-called International Human Rights Law (IHRL), a branch of International Law whose importance stems not only from its juridification of international relations, i.e., from the creation of norms and international bodies aimed at ensuring the protection of Human Rights, but also, and above all, from the fact that from that moment on, the protection of these rights became enshrined as the main objective of the international community.

IHRL supports the need to give full effectiveness to individual rights, by establishing norms that protect life, human dignity, freedom, equality, among other things, and by providing legal and political instruments for the implementation of Human Rights. ${ }^{45}$ This branch of International Law therefore seeks an ethical reconstruction and unification, founded on human dignity, through the creation of rules and a system for monitoring the application of those rules for the protection of humans, and by consecrating the need to respect Human Rights as a form of limiting the abusive use of power. ${ }^{46}$

The emergence of IHRL led to major changes in International Law, particularly in the fact that it emphasized individuals, and not only States, as subjects of International Law, and stipulated that States must respect minimum standards of protection or otherwise be subject to international accountability. The consolidation of this new specialized branch, aimed at protecting human dignity, is one of the greatest achievements of the humanization or constitutionalization of International Law, as it allowed the creation of complex mechanisms aimed at protecting the individual in the international context. ${ }^{47}$

Through this movement, people were no longer reduced to mere objects of international protection, but became recognized as the legitimate holders of the rights emanating from the international legal order. In the words of Trindade, this was the "great legal revolution operated by International Human Rights Law throughout the second half of the twentieth century, and today

43 PETERS, Anne. Compensatory Constitutionalism: the function and potential of fundamental international norms and structures, p. 589.

44 ACOSTAALVARADO, Paola Andrea. Del diálogo interjudicial a la constitucionalización del derecho internacional: la red judicial latinoamericana como prueba y motor del constitucionalismo multinivel, p. 179.

45 TAIAR, Rogério. Direito Internacional dos Direitos Humanos: uma discussão acerca da relativização da soberania face à efetivação da proteção internacional dos Direitos Humanos, p. 195.

46 AMARAL JÚNIOR, Alberto; JUBILUT, Liliana Lyra. O Direito Internacional dos Direitos Humanos e o Supremo Tribunal Federal. In: (Coord.). O STF e o Direito Internacional dos Direitos Humanos. São Paulo: Editor Quartier Latin of Brasil, 2009, p. 30-49.

47 ACOSTAALVARADO, Paola Andrea. Del diálogo interjudicial a la constitucionalización del derecho internacional: la red judicial latinoamericana como prueba y motor del constitucionalismo multinivel, p. 196-197. 


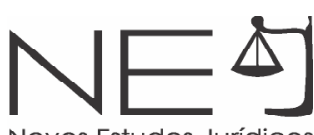

consolidated in irreversible form" (our translation) ${ }^{48}$. With the consolidation of IHRL, it has been possible to establish norms and international mechanisms for the protection of Human Rights as fundamental values of humanity, leading to the consolidation of an international community with policies aimed at protecting these individuals. ${ }^{49}$

By recognizing that individuals have rights which are protected not only by States, but also by International Law, and holding the State accountable for failure to comply with the international standards, this new branch of International Law has done away with the traditional binary relationship between the State and the individual when it comes to human/fundamental rights. In this scenario, there are several changes, with the extension of rights holders, the establishment of mechanisms to hold the State accountable in the international arena, and the politicization of the subject, due to the need for ongoing commitments by the States and other international actors, in order to make Human Rights effective at an international level. ${ }^{50}$

By focusing on the protection of the rights of individuals, the IHRL began to address issues that were traditionally viewed as being constitutional in nature, as the rights intended to protect the individual against abuses were considered of exclusive internal competence. Furthermore, with the institution of a complex international corpus juris for the protection of Human Rights, as seen in the previous topic, and the assumption of inherent characteristics of Constitutional Law, there is a redefinition of what was previously the exclusive jurisdiction of States. ${ }^{51}$ As Peters points out:

\begin{abstract}
States are no longer a black box for international law, because international organizations, treaty bodies, foreign states, officials of foreign state organs, and transnational nongovernmental organizations (NGOs) scrutinize and assess national constitutional systems, and impose material standards of governance relating, inter alia, to the protection of human rights and democracy. This also means that both spheres (the international and the national) can no longer be neatly separated. They already complement each other and should do so even more in the future. ${ }^{52}$
\end{abstract}

Similarly, Antonios Tzanakopoulos points out that what is evident in the current scenario is a process of regulation, by the international jurisdiction, of matters previously reserved for domestic scope, with the purpose of regulating state conduct within their own jurisdictions and thus, avoiding Human Rights violations. As the theorist highlights:

Not only is there a proliferation of regulation taking place at the international level, but

48 In the original: "grande revolução jurídica operada pelo Direito Internacional dos Direitos Humanos ao longo da segunda metade do século XX e hoje consolidada de modo irreversível". In: TRINDADE, Antônio Augusto Cançado. Desafios e conquistas do Direito Internacional dos Direitos Humanos no início do século XXI. 2006. Available at: <https://www.oas.org/dil/e sp/407-490\%20cancado\%20trindade\%200EA\%20CJI\%20 \%20.def.pdf>. Accessed on 15 May 2018.

49 ACOSTAALVARADO, Paola Andrea. Del diálogo interjudicial a la constitucionalización del derecho internacional: la red judicial latinoamericana como prueba y motor del constitucionalismo multinivel, p. 203.

50 DIMOULIS, Dimitri. Teoria geral dos direitos fundamentais. 5. ed. São Paulo: Atlas, 2014

51 TAIAR, Rogério. Direito Internacional dos Direitos Humanos: uma discussão acerca da relativização da soberania face à efetivação da proteção internacional dos Direitos Humanos, p. 196.

52 PETERS, Anne. Compensatory Constitutionalism: the function and potential of fundamental international norms and structures, p. 591. 
also a great number of norms adopted at that level is characterized by a distinct and peculiar "directionality." Many international norms are no longer traditional, almost exclusively "extrovert" or "outward-looking" obligations imposed on States with respect to their interaction with other States on the international plane. Rather, most are increasingly "introvert" or "inward-looking" norms; that is to say, norms that aim to regulate State conduct within the domestic jurisdiction (or, to put it another way, norms whose intended operation is through—direct or indirect—implementation within the domestic jurisdiction)..$^{53}$

In this context, the States are no longer the only actors of International Law, their rights are not the only ones protected, and their will is not the only source of legitimacy. The observance of Human Rights ceases to be a private interest of the State and becomes a matter of international interest, and as such, also subject to regulation by International Law. ${ }^{54}$ This view is at the heart of the process of constitutionalization, as it implies a recognition that the various challenges faced by humankind can no longer be resolved through a balance between State interests, but only in the common interest of man. ${ }^{55}$ In this respect, the need to protect common values of humanity by the international order is recognized, these values being "essential coordinates. Today they are the most deeply anchored principles in law. Nobody seriously argues against them, and their concept is widely accepted, at least as a fundamental core. No government can afford to challenge human rights as an ideal" 56 , which, in short, implies the recognition of the existence of international norms of a constitutional nature in International Law.

The establishment of Human Rights at the international level, therefore, encourages States, regardless of their differences, to behave in a way that is in keeping with the minimum values and precepts of the international treaties for the protection of Human Rights. ${ }^{57}$ The two systems seek to achieve the same goal, as they share the same foundation, that is, the primacy of the value of human dignity. They are, therefore, "two faces of the same process of valorization of the human being, in the axiological hierarchy of the international community, established from the same historical events" 58 . Complementarity arises precisely from the fact that most sources of law enforcement are outside the constitutional text ${ }^{59}$, requiring a convergence between these internal and external sources for the adequate and integral protection of Human Rights.

53 TZANAKOPOULOS, Antonios. Domestic Courts in International Law: the international judicial function of national courts. Loyola of Los Angeles International and Comparative Law Review, Los Angeles, v. 34, n. 133, jan. 2011, p. 138.

54 HENKIN, Louis. The age of rights. Nova York: Columbia University Press, 1990.

55 BRYDE, Brunn-Otto. International Democratic Constitutionalism. In: MACDONALD, Ronald St. John; JOHNSTON, Douglas (Ed.). Towards World Constitutionalism: issues in the legal ordering of the world community. Leiden: Martinus Nijhoff Publishers, 2005.

56 COTTIER, Thomas. Multilayered governance, pluralism, and moral conflict. Indiana Journal of Global Legal Studies, v. 16, n. 2, p. 647-679, 2009.

57 TRINDADE, Antônio Augusto Cançado. Desafios e conquistas do Direito Internacional dos Direitos Humanos no início do século XXI, p. 414.

58 AMARAL JÚNIOR, Alberto; JUBILUT, Liliana Lyra. O Direito Internacional dos Direitos Humanos e o Supremo Tribunal Federal, p. 33.

59 BALAGUER CALLEJÓN, Francisco. A relação dialética entre identidade constitucional nacional e europeia, no quadro do Direito Constitucional Europeu. ONIO EU Law Journal, v. 3, n. 1, p. 10-24, Jan. 2017. 
The process of constitutionalization of International Law, thus, ends up reinforcing the constitutionally guaranteed rights themselves, strengthening mechanisms for the protection of Human Rights, in a process of convergence of International Law and Constitutional Law for the protection of values common to both the systems.

\section{CONCLUSION}

Due to a process of juridification of international relations, it is envisaged that through progressive development, International Law has effectively constitutionalized itself, or rather, it has come to mimic institutes previously reserved only for Constitutional Law. Despite the theoretical clashes that exist over the possibility of recognizing norms of a constitutional nature in International Law, it is International Human Rights Law that decisively consolidates the constitutionalization of International Law, precisely because it makes subjects, previously regulated only by State Law, the focus of International Law, and because it acts as an important apparatus for ensuring international accountability.

By assuming characteristics of Constitutional Law, IHRL establish limits on the unrestricted power of States and establishes minimum parameters of protection, all aimed at achieving the ultimate objective of the international community, which is the effective protection of the individual, in all aspects. As a consequence of this fact, there is a perception, by the international community, of the need to international standards for the protection of Human Rights.

It is evident that the process of constitutionalization has great relevance for the protection of Human Rights, as it provides a means of increasing the powers conferred to the international norms on the protection of the human person. Through this process, IHRL is now seen as mandatory by all States, in order to achieve the essential objectives of the international community as a whole, with regard to the protection of the human being and the prevention of Human Rights violations.

\section{REFERENCES}

ACOSTA ALVARADO, Paola Andrea. Del diálogo interjudicial a la constitucionalización del derecho internacional: la red judicial latinoamericana como prueba y motor del constitucionalismo multinivel. 2013. Thesis (PhD in International Law and International Relations) - Complutense University of Madrid, Ortega e Gasset University Research Institute, Madrid, 2013.

AMARAL JÚNIOR, Alberto; JUBILUT, Liliana Lyra. O Direito Internacional dos Direitos Humanos e o Supremo Tribunal Federal. In: (Coord.). O STF e o Direito Internacional dos Direitos Humanos. São Paulo: Editor Quartier Latin of Brasil, 2009. 
BALAGUER CALLEJÓN, Francisco. A relação dialética entre identidade constitucional nacional e europeia, no quadro do Direito Constitucional Europeu. ONIO EU Law Journal, v. 3, n. 1, p. 10-24, jan. 2017.

BRYDE, Brunn-Otto. International Democratic Constitutionalism. In: MACDONALD, Ronald St. John; JOHNSTON, Douglas (Ed.). Towards World Constitutionalism: issues in the legal ordering of the world community. Leiden: Martinus Nijhoff Publishers, 2005.

CARVALHO, Oswaldo Ferreira de. A constitucionalização e a internacionalização dos direitos fundamentais. Public Law Review, v. 8, n. 43, p. 46-64, 2011.

CASTILLO DAUDÍ, Mireya. Derecho internacional de los derechos humanos. 2. ed. Valencia: Tirant Lo Blanch, 2006. CLAUDE, Richard Pierre; WESTON, Burns $\mathrm{H}$. (Ed.). Human rights in the world community: issues and action. Philadelphia: University of Pennsylvania Press, 1989.

CLAUDE, Richard Pierre; WESTON, Burns H. (Ed.). Human rights in the world community: issues and action. Philadelphia: University of Pennsylvania Press, 1989.

COTTIER, Thomas. Multilayered governance, pluralism, and moral conflict. Indiana Journal of Global Legal Studies, v. 16, n. 2, p. 647-679, 2009

DIMOULIS, Dimitri. Teoria geral dos direitos fundamentais. 5. ed. São Paulo: Atlas, 2014.

FASSBENDER, Bardo. The United Nations Charter as Constitution of the International Community. Columbia Journal of Transnational Law, v. 36, n. 3, p. 529-619, 1998.

HENKIN, Louis. The age of rights. Nova York: Columbia University Press, 1990.

HESSE, Konrad. Elementos de Direito Constitucional da República Federal da Alemanha. Translation of Luís Afonso Heck. Porto Alegre: Editora Safe, 1998.

KELSEN, Hans. Teoria Geral do Estado e do Direito. Translation of Luis Carlos Borges. São Paulo: Martins Fontes, 2000.

LUÑO, Pedro. Los derechos fundamentales. 8. ed. Madrid: Editorial Tecnos, 2004.

PERENICE, Ingolf. The Treaty of Lisbon: Multilevel Constitutionalism in action. Columbia Journal of European Law, Columbia, n. 15, 2009.

PETERS, Anne. Compensatory Constitutionalism: the function and potential of fundamental international norms and structures. Leiden Journal of International Law, Leiden, v. 19, n. 3, p. 579-610, 2006.

PIOVESAN, Flávia. Direitos Humanos e o Direito Constitucional Internacional. 14. ed. São Paulo: Saraiva, 2013.

RAMOS, André de Carvalho. A relação entre o Direito Internacional e o Direito interno no contexto da pluralidade de ordens jurídicas. In: BRANDT, Leonardo Nemer Caldeira (Org.). Brazilian Yearbook of International Law. Belo Horizonte: CEDIN, 2012, v. 1, n. 12, p. 99-134.

SCHMITT, Carl. Teoria de la Constitución. Madri: Alianza editorial, 1982.

SLOBODA, Pedro Muniz Pinto; TAVARES, Sérgio Maia. Direito Interno e Direito Internacional: integração sistêmica. In: MENEZES, Wagner; ANUNCIAÇÃO, Clodoaldo Silva da; VIEIRA, Gustavo Menezes (Org.). Direito Internacional em expansão. Belo Horizonte: Arraes Editores, 2014, p. 504-514.

SMEND, Rudolf. Constitución y Derecho Constitucional. Madrid: Centro de Estudios Constitucionales, 1985.

TAIAR, Rogério. Direito Internacional dos Direitos Humanos: uma discussão acerca da relativização da soberania face à efetivação da proteção internacional dos Direitos Humanos. 2009. Thesis (PhD in Human Rights) - University of São Paulo, São Paulo, 2009. 
TRINDADE, Antônio Augusto Cançado. Desafios e conquistas do Direito Internacional dos Direitos Humanos no início do século XXI. 2006. Available at: <https://www.oas.org/dil/e sp/407-490\%20cancado\%20trindade\%200EA\%20 CJI\%20\%20.def.pdf>. Access on May 152018.

TZANAKOPOULOS, Antonios. Domestic Courts in International Law: the international judicial function of national courts. Loyola of Los Angeles International and Comparative Law Review, Los Angeles, v. 34, n. 133, p. 133-168, jan. 2011.

VERDROSS, Alfred. Die Verfassung der Völkerrechtsgemeinschaft. Vienna: J. Springer, 1926.

SIMMA, Bruno. Universelles Völkerrecht: Theorie und Praxis. 3. ed. Berlim: Duncker \& Humboldt, 1984.

RECEBIDO EM: 27/07/2019

APROVADO EM: 04/10/2019 